\title{
THE INVASIVE RAPA WHELK RAPANA VENOSA (VALENCIENNES 1846): STATUS AND POTENTIAL ECOLOGICAL IMPACTS IN THE RÍO DE LA PLATA ESTUARY, ARGENTINA-URUGUAY
}

\author{
DIEGO A. GIBERTO ${ }^{1,2}{ }^{2}$ CLAUDIA S. BREMEC ${ }^{1,2}$ LAURA SCHEJTER, ${ }^{1,2}$ \\ AGUSTÍN SCHIARITI, ${ }^{1,2}$ HERMES MIANZAN ${ }^{1,2}$ AND EDUARDO M. ACHA ${ }^{1,2,3}$ \\ ${ }^{1}$ Consejo Nacional de Investigaciones Científicas y Técnicas (CONICET), Rivadavia 1906, Buenos \\ Aires, Argentina; ${ }^{2}$ Instituto Nacional de Investigación y Desarrollo Pesquero (INIDEP), Paseo V. \\ Ocampo $N^{\circ} 1$ Mar del Plata, Argentina; ${ }^{3}$ Departamento de Ciencias Marinas (FCEyN), Universidad \\ Nacional de Mar del Plata, Funes 3250, Mar del Plata. Argentina
}

\begin{abstract}
Recent range extensions of the invasive rapa whelk Rapana venosa, biological data of the population and possible ecological impacts on the food webs of the Río de la Plata estuary are presented. A total of 41 rapa whelks and 21 egg capsules were collected between February 2004 and March 2006. Specimens were found all over the mixohaline waters of the estuary, with records off Montevideo, Samborombón Bay and off Punta Rasa. Specimens ranged between 28 and $120 \mathrm{~mm}$ shell length. Almost all $R$. venosa presented epibionts all over the shell, suggesting an exposed lifestyle. Egg-masses were attached to specimens of $R$. venosa, debris and plastic garbage. The spatial distribution of $R$. venosa within the estuary was coupled with the spatial distribution of Mactra isabelleana, a typical subtidal bivalve of mixohaline waters. The implications for the food webs of the estuary, including possible predators, are discussed. The presence of $R$. venosa in muddy sediments together with the finding of egg-capsules over the specimens, and the low salinity values at which it is found in the Río de la Plata estuary, confirmed the high plasticity of $R$. venosa and the potential capability of successfully invading novel environments.
\end{abstract}

KEY WORDS: exotic species, invasion, Rapana venosa, Muricidae, Rapa whelk, Mactra isabelleana, Ostrea puelchana, food webs, Río de la Plata, Southwestern Atlantic

\section{INTRODUCTION}

The large Asian gastropod Rapana venosa Valenciennes 1846 (Neogastropoda, Muricidae) is a predatory mollusc native to the Sea of Japan, Yellow Sea, Bohai Sea and the East China Sea to Taiwan (ICES, 2004). This species was discovered out of its native biogeographic range in the Black Sea, and it has subsequently spread throughout the Sea of Azov, and the Aegean, Adriatic and North Seas (for complete lists of localities see ICES, 2004). The first collection of $R$. venosa in North America was made in the Chesapeake Bay on the East Coast of the United States in 1998 (Harding \& Mann 1999). The first report of rapa whelks in South America was made by Scarabino et al. (1999) and Pastorino et al. (2000) from collections in the Rio de la Plata estuary, ArgentinaUruguay.

This generalist predator of subtidal mollusks usually feeds on bivalves of economic interest like oysters, mussels and clams (Harding \& Mann 1999, Savini et al. 2004), and has been identified as the prime reason for the collapse of several banks of mussels and oysters in the Black Sea (Drapkin 1963, Zolotarev 1996). Adult Rapana venosa are found in water temperatures between $4^{\circ} \mathrm{C}$ and $27^{\circ} \mathrm{C}$ (Chung et al. 1993) and salinities ranging from 28-33 in Korean waters (Korea Oceanographic Data Center, http:// kodc2.nfrdi.re.kr:8001/home/eng/main/index.php). Furthermore, in nonnative localities $R$. venosa is found in estuarine salinities (Scarabino et al. 1999, Pastorino et al. 2000, Mann \& Harding 2000, 2003; ICES 2004). Their high fecundity (Chung et al. 1993), dispersal assisted by a planktonic larvae that is capable of remaining planktonic between 14 and 80 days in estuarine and marine waters (Mann \& Harding 2003), and fast growth (Harding \& Mann

*Corresponding author. E-mail: diegogiberto@inidep.edu.ar
2005 ) make $R$. venosa a potentially successful invader worldwide (Savini et al. 2004).

A recent general review of exotic species in the Southwestern Atlantic $\left(34^{\circ} \mathrm{S}\right.$ to $\left.54^{\circ} \mathrm{S}\right)$ revealed that most of the exotic species of the region are concentrated in Buenos Aires Province (northern Argentina), where major commercial harbors are located (Orensanz et al. 2002). At this region, the Río de la Plata ( $34^{\circ}$ to $36^{\circ} 30^{\prime} \mathrm{S}, 55^{\circ}$ to $58^{\circ} 30^{\prime} \mathrm{W}$ ) forms one of the largest estuarine systems of South America ( $c a .38,000 \mathrm{~km}^{2}$ of mixohaline area). This river is one of the large waterways of South America. Two of the major ports in the region, Buenos Aires (Argentina) and Montevideo (Uruguay), lie along its shores generating an intense nautical traffic. The estuary is also the maritime access to the highly complex fluvial system named "Hidrovia," communicating with the Amazon Basin (Bisbal 1995, Mianzan et al. 2001).

Although it is known that ships are one of the main sources of introduction of exotic species via fouling or ballast water, regulations regarding the later in Argentina are not strictly enforced (Orensanz et al. 2002). In agreement, this was the mechanism suggested for the introduction of Rapana venosa in the Río de la Plata estuary (Pastorino et al. 2000). Early collections of Rapana venosa in the estuary corresponded to adult specimens found in the Rouen and English Banks in May 1998, several egg masses along the Uruguayan coast, between Montevideo and Punta del Este in December 1998 to February 1999 (Scarabino et al. 1999), one specimen (95 mm shell length) in November 1999 off Samborombón Bay (Pastorino et al. 2000), another specimen ( $89 \mathrm{~mm}$ shell length) collected in November 2001 off Montevideo (Rodrigues Capitulo et al. 2002), and recently (spring 2002), several specimens caught in a fisheries research survey along the outer part of the estuary (Carranza et al. in press) (see Fig. 1). However, studies F1 about the potential extent of establishment of this gastropod over time or possible ecological impacts on the food webs of the estuary 


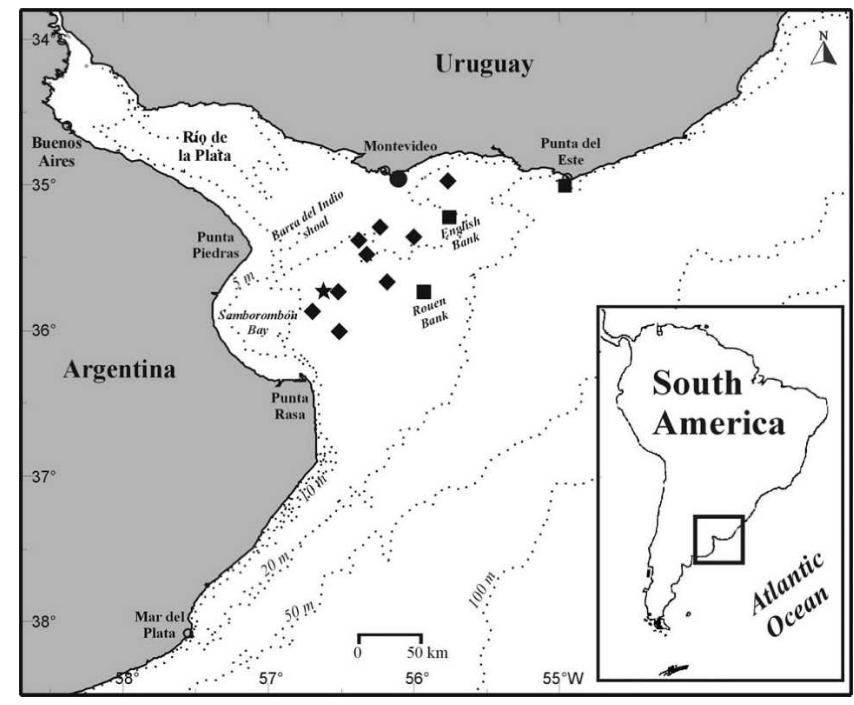

Figure 1. The Río de la Plata estuary and adjacent marine zones, with indication of collection sites of Rapana venosa in $1998(\bullet)$ and $1999(\star)$ (from Scarabino et al. 1999 and Pastorino et al. 2000), 2001 (•) (from Rodrigues Capitulo et al. 2002) and 2002 ( $\diamond$ ) (from Carranza et al. in press) (see text for details).

are lacking. Therefore, the main goals of this study are to provide data describing the status of $R$. venosa in the Río de la Plata estuary and discuss the potential ecological impact of this species in the region.

\section{MATERIALS AND METHODS}

Study Area

The Río de la Plata estuary is an extensive and shallow coastal plain estuary. It's bottom shows a gentle slope with depths lesser than $25 \mathrm{~m}$ (10 m mean depth). Fine sediments of fluvial origin occupy most of the estuary, but the outer region is covered by deposits of marine sands (Urien 1972). This estuary is characterized by a quasi-permanent salt wedge regimen. Fresher, and therefore lighter, water flows out of the estuary in the surface layer and a deeper flow brings water from the sea into the estuary. Salinities (hereafter salinity is reported following the Practical Salinity Scale) at the bottom of the estuary range from 0 to $>33$ (Guerrero et al. 1997). The estuary therefore becomes a typically two-layer system characterized by strong vertical stratification, which gradually weakens seaward. The maximum upriver penetration of the salt wedge is associated to a submersed bar across the river (Barra del Indio shoal). A well-developed turbidity front characterizes the innermost part of the estuary. This turbidity maximum is caused by the flocculation of suspended matter at the tip of the salt wedge, and resuspension of sediment caused by tidal stirring (Framiñan \& Brown 1996). A wind driven, two-way discharging pattern has been described for the estuary (Guerrero et al. 1997). During spring and summer months the river plume moves southward, to the Argentine coast. During fall-winter, the plume manifest mostly towards NNE, along the Uruguayan coast, and can be traced reaching southern Brazil (Piola et al. 2000).

Benthic fauna is characterized by 2 major groups: a low diversity estuarine assemblage (muddy bottoms, salinities between 0.5 and 33), dominated by infaunal bivalves and a marine assemblage (sandy bottoms, salinities $>33$ ), with higher values of diversity and the occurrence of oysters and mussels banks (Giberto et al. 2004, Giberto \& Bremec In prep.). Bottom type, salinity and the presence of the turbidity front are considered the main physical variables in structuring benthic communities of the Río de la Plata estuary (Giberto et al. 2004).

\section{Sampling and Data Analysis}

Rapa whelks and environmental data came from stations sampled during February 2004, December 2005, February and March 2006, in routine fisheries research cruises carried out in the Río de la Plata estuary and adjacent area by the R/V "Capitan Cánepa" (INIDEP) (Table 1). Faunal samples were taken with a T1 bottom trawl designed to capture juvenile fishes (10-mm mesh size). Collected specimens of Rapana venosa were frozen on board and examined later at laboratory. For each specimen total weight (shell + body wet weight) (TW), shell length (SL), aperture height $(\mathrm{AH})$, aperture width (AW) and shell thickness (ST) were measured, following Savini et al. (2004). Dimensions were taken using a digital caliper $(0.1 \mathrm{~mm})$. The epibiotic invertebrates on the studied material were identified. The number of eggs and capsules of the egg masses were counted and measured under binocular microscope. Fecundity was estimated as total number of eggs in total eggs capsules (see Chung et al. 1993).

The allometric relationship between SL and TW was analyzed with simple linear regression (Sokal \& Rohlf 1999).

Oceanographic sampling was performed with a Sea Bird-19 CTD (Conductivity Temperature Depth profiler), at the beginning of each sampling tow. Salinity is reported following the Practical Salinity Scale. Sediment type was characterized using data available from the literature (Urien 1972) and from Giberto \& Bremec (In prep.).

To assess potential ecological impacts on the food webs of the area, we analyzed the occurrence of typical subtidal bivalve species, which reach high densities in estuarine and marine adjacent waters (Mactra isabelleana, Ostrea puelchana and Mytilus edulis platensis, In doing so, we used macrofauna data (1975-2005) compiled in Giberto \& Bremec (2003, In prep.) and Giberto et al. (2004).

\section{RESULTS}

A total of 41 rapa whelks and 21 egg eapsules $\Lambda^{\text {were collected }}$ in summer research cruises between February 2004 and March

TABLE 1.

Summary of sampling data from the Río de la Plata estuary.

\begin{tabular}{lccccc}
\hline \hline Sampling Date & Gear & Depth $(\mathbf{m})$ & Salinity & Temperature $\left({ }^{\circ} \mathbf{C}\right)$ & Sediment \\
\hline February 2004 & Bottom trawl & $4-9$ & $13.5-26.7$ & $21.8-23.2$ & Mud \\
December 2005 & Bottom trawl & $8-11$ & $14.8-30.8$ & $17.5-20.4$ & Mud \\
Feb-March 2006 & Bottom trawl & $4-13$ & $12.7-20.3$ & $21.4-22.6$ & Mud-Sand \\
\hline \hline
\end{tabular}


2006 (Fig. 2 and Table 2). Rapana venosa was found all over the mixohaline waters of the estuary, with constants records off Montevideo and in Samborombón Bay. In 2005 and 2006 R. venosa was found in southern locations, at higher salinities off Punta Rasa (see Fig. 2 and Table 2). Specimens ranged between 28 and 120 $\mathrm{mm}$ SL. SL-frequency and distribution of Rapana venosa in the estuary for each cruise is shown in Figure 2. Total weight ranged between $2.8 \mathrm{~g}$ and $351.5 \mathrm{~g}$. Figure 3 shows the result of the regression analysis between SL (independent variable) and TW (dependent variable).

Rapa whelks were collected in shallow muddy (36 specimens) and sandy ( 5 specimens) bottoms. The associated fauna in muddy bottoms were the bivalve Mactra isabelleana (see Fig. 2d), the shrimp Artemesia longinaris, the gastropods Buccinanops sp. and Heleobia australis, the polychaete Alitta succinea and the cumacean Diastylis sp. In sandy bottoms $R$. venosa was found together with the oyster $O$. puelchana in three sampling stations (see Fig. $2 \mathrm{~d}$ for the distribution of possible preys).

Undetermined bryozoans (63\%) and barnacles (Balanus sp., $78 \%$ ) were the most frequent epibionts colonizing all over the shell
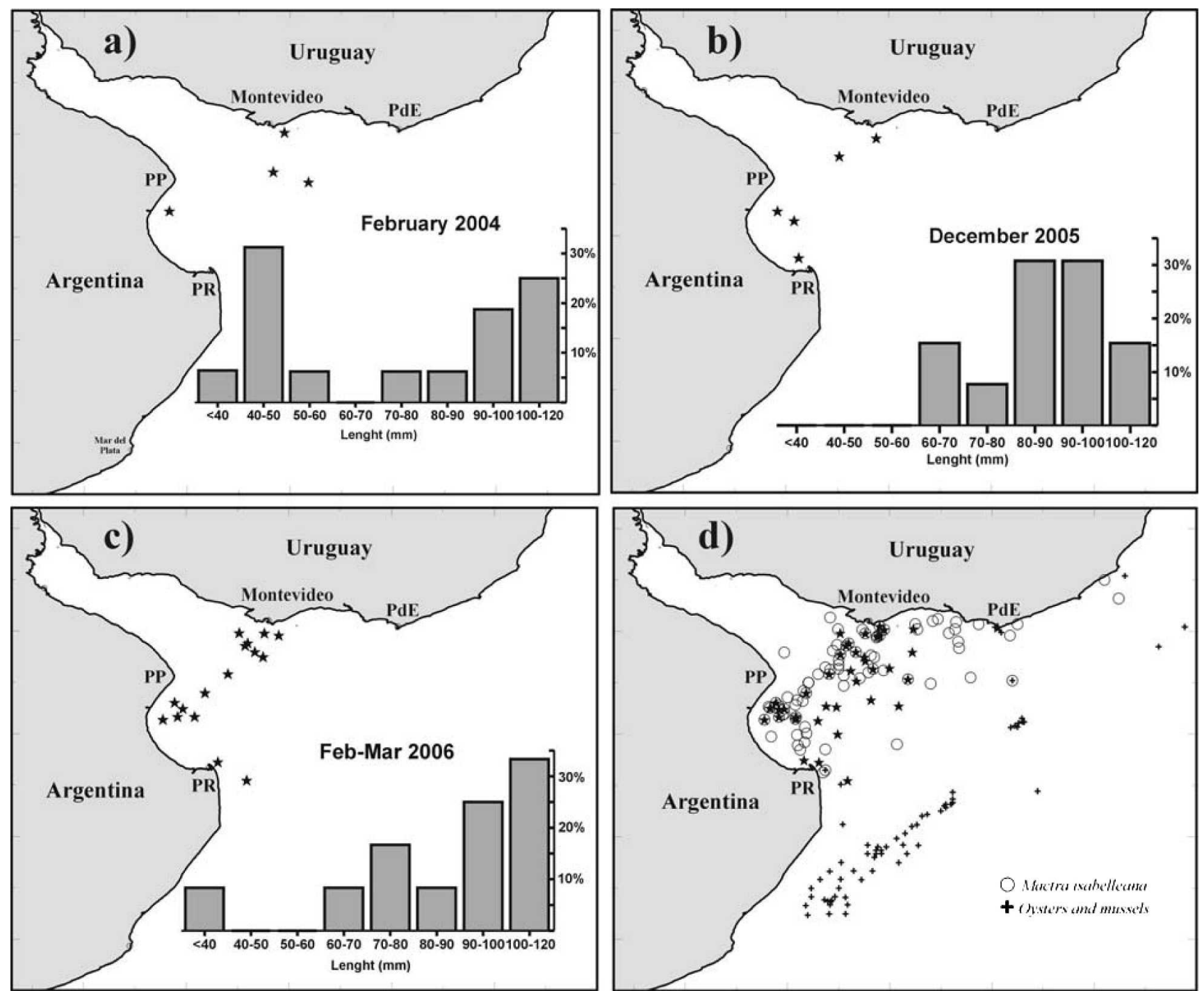

Figure 2. Shell length-frequency and distribution of Rapana venosa $(\star)$ in the study area during each cruise (a to c). Complete known range distribution of $R$. venosa $(\star)$ and potential bivalve preys (banks of Mactra isabelleana, Ostrea puelchana and Mytilus edulis platensis) (d). PP, Punta piedras; PR, Punta Rasa; PdE, Punta del Este. of Rapana venosa $(n=36)$. Hydrozoan branches $(30 \%)$ were also found. Undetermined small sea anemones, undetermined chitons and polychaete tubes (Serpulidae) were found occasionally. Five rapa whelks lack epibionts completely. Polydora sp. (Polychaeta) infestations were found in 6 specimens.

A total of 21 egg masses were found. Eight of them were attached to debris and plastic garbage, whereas 13 were found attached to larger whelks. Capsules $(n=30)$ per whole egg mass varied between 108 and 700, and eggs per capsules varied from 434-890. Fecundity estimations were in the range 76,156-85,323 eggs per individual. The egg capsules contained shelled larvae having the operculum and larval shell $(\sim 0.4 \times 0.3 \mathrm{~mm})$. Larvae with "coned" shells were found with a frequency of $\sim 10 \%$ (Fig. 4). F4 Egg capsules from December were pale black color (average of 717 eggs per capsule), whereas several capsules from February were empty with the exit hole bored, or dead with a violet color (average of 568 eggs per capsule), and capsules from March were all empties. Collected capsules, including the curved tip, measured $18.5-29.5 \mathrm{~mm}$ in length, and $1.7-2.5 \mathrm{~mm}$ in width at the smaller diameter at the base. 
TABLE 2.

Collection of Rapana venosa and biometric variables in the Río de la Plata estuary.

\begin{tabular}{lccccc}
\hline \hline & Shell Length & $\begin{array}{c}\text { Aperture } \\
\text { Height } \\
(\mathbf{m m})\end{array}$ & $\begin{array}{c}\text { Aperture } \\
\text { Width } \\
(\mathbf{m m})\end{array}$ & $\begin{array}{c}\text { Thickness } \\
(\mathbf{m m})\end{array}$ \\
\hline Sampling Date & $\boldsymbol{n}$ & $36.82-111.92$ & $28.4-94.9$ & $11.3-44.8$ & $0.6-4.9$ \\
February 2004 & 16 & $68.8-106.8$ & $56-89.2$ & $24.3-41.7$ & $1.6-3.3$ \\
December 2005 & 13 & $28.6-119.3$ & $21.5-99.1$ & $9.04-52.5$ & $0.5-3.4$ \\
Feb-March 2006 & 12 & &
\end{tabular}

\section{DISCUSSION}

The rapa whelk Rapana venosa successfully spread over the muddy bottoms of the estuary since their early records off Samborombón Bay and along the Uruguayan coast (Pastorino et al. 2000, Scarabino et al. 1999, Rodrigues Capitulo et al. 2002). Their range extension is now at Argentinean and Uruguayan coastal lines. The finding of invasive marine species in coastal and estuarine waters is an already widespread phenomenon. The impacts of such introductions are unpredictable, and not all of them become a successful resident in the new environments. However, the presence of small specimens of rapa whelk (between 28 and $48 \mathrm{~mm}$ $\mathrm{SL}$ ), and egg capsules with operculated and shelled larvae, confirmed that the population of $R$. venosa is sexually mature and actively breeding in the region, as was suggested in previous works (Scarabino et al. 1999, Pastorino et al. 2000).

Biometric variables measured were in the range reported by Savini et al. (2004) for the Northern Adriatic Sea for similar shell length ranges. Besides their smaller size, the allometric growth of the snails collected in this study presented similar slope values than larger Adriatic species (3.21 and 3.37 for rock and sand samples, Savini et al. 2004). The record of small specimens in other localities where $R$. venosa was introduced is a rare event, because most of the data usually come from commercial fisheries that selectively catch larger snails (Harding \& Mann 1999, ICES

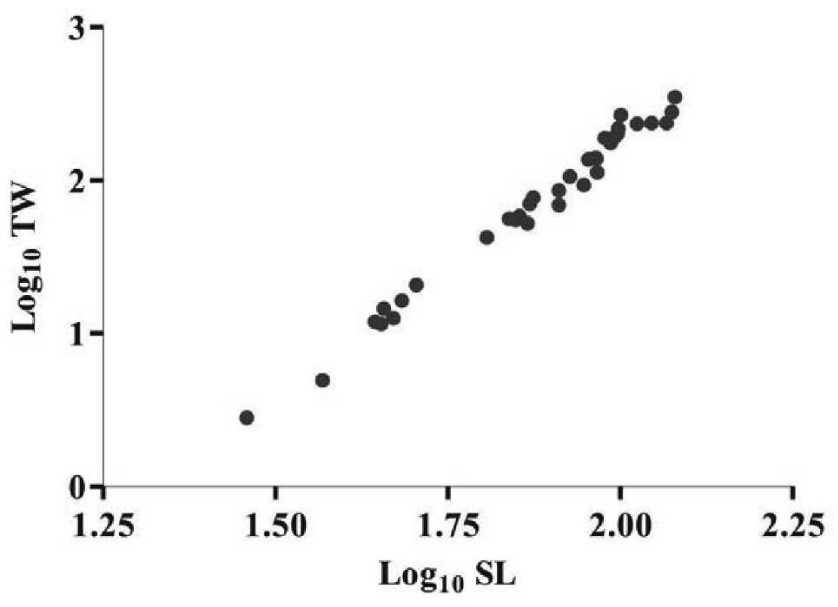

$\log _{10} \mathrm{TW}=3.39 \log _{10} \mathrm{SL}-4.52$

$\mathrm{R}^{2}=0.985$

Figure 3. Linear relationship (data $\log _{10}$ transformed) between shell length ( $\mathrm{mm}$ ) (independent variable) and total weight (g) (dependent variable) for samples of Rapana venosa collected in the Río de la Plata estuary between 2004 and 2006. Equation and regression coefficient $\left(\mathbf{R}^{2}\right)$ are indicated. SL, shell length; TW, total weight $\wedge$
2004) or because of possible distinct habitat preferences of juveniles (Savini et al. 2004). However, our data from the Río de la Plata estuary do not show segregation by size classes.

Almost all Rapana venosa specimens presented epibionts all over the shell, which suggests an exposed lifestyle. Similar results were found by Savini et al. (2004) for specimens living on hard rock. On the contrary, other studies under field and laboratory conditions found that rapa whelks are nocturnal and remain burrowed most of the day, avoiding settlement by epifaunal biota (Harding \& Mann 1999, 2005). Environmental conditions in the Río de la Plata estuary may conduct to a different behavior. The light penetration in mixohaline waters is really poor, with approximately $99 \%$ of the incident radiation lost at around $2 \mathrm{~m}$ depth (Acha et al. submitted), and the sedimentation rate is high (Urien 1972), which means that adult rapa whelks may be exposed during longer periods of time than in other habitats. It is also remarkable that the organisms that encrust the shells of this gastropod are not usually found in the muddy bottoms of the estuary (Giberto et al. 2004), with the exception of barnacles colonizing small specimens of Mactra isabelleana (Giberto, pers. obs.). This reflects the lack of hard bottoms in the estuary and the importance of $R$. venosa shells as suitable settlement substrates for epibionts larvae. Moreover, $R$. venosa egg-masses were attached to debris and plastic garbage, which are concentrated over the Barra del Indio shoal by the frontal dynamics (Acha et al. 2003).

Habitat quality is very important for the successful colonization of novel environments. Salinity ranges of the estuary are within the limits at which the species has been found in other locations (ICES 2004), although in this area Rapana venosa was always found at low salinity waters (see Table 1 and Carranza et al. in press). Thermal seasonal range of the estuary $\left(10^{\circ} \mathrm{C}\right.$ to $23^{\circ} \mathrm{C}$, Guerrero et al. 1997) is in coincidence with breeding tolerances for $R$. venosa $\left(13^{\circ} \mathrm{C}\right.$ to $\left.26^{\circ} \mathrm{C}\right)$ recorded by Chung et al. (1993). These authors also reported a 17 -day incubation period at $18^{\circ} \mathrm{C}$ to $20^{\circ} \mathrm{C}$ in laboratory conditions, with females laying egg-masses during all the reproductive period in summer. Specimens of this estuary seem to follow this pattern, because the egg-capsules found in November contained embryos at a morula-gastrula stage (Pastorino et al. 2000), whereas the capsules found in this study (DecemberFebruary) were with normal and "coned" shelled larvae or empty. "Coned" shells could be malformations leading to nonviable larvae. Egg-masses were attached to specimens of $R$. venosa and debris and plastic garbage, which seems to be an alternative reproductive strategy to deal with the absence of any other primary settlement substrate. These findings are in coincidence with data from the outer estuary by Carranza et al. (in press), which also found egg masses attached to plastic debris and garbage.

The spatial distribution of Rapana venosa within the estuary 

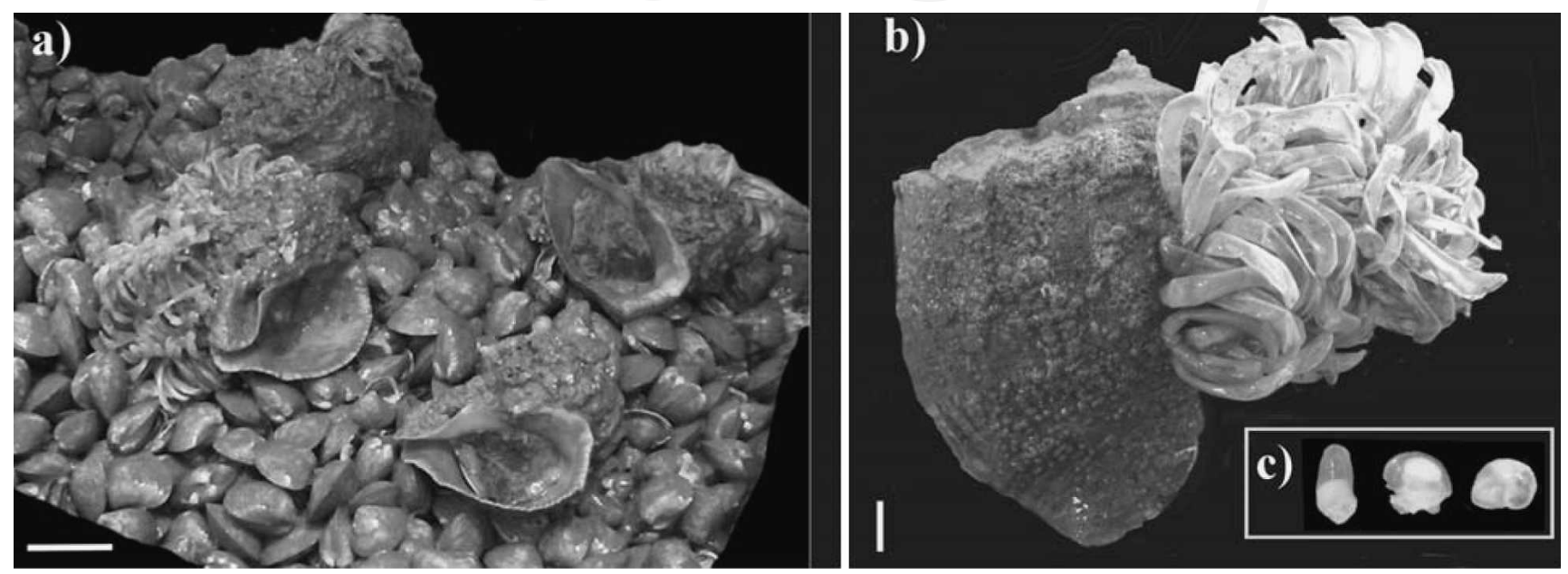

Figure 4. Adults of Rapana venosa collected in the Río de la Plata estuary over Mactra isabelleana banks (a, scale bar: 50 mm). Egg cases were attached to the specimens (b, scale bar: $10 \mathrm{~mm}$ ) and contained "coned" shells forms and normal shelled larva of $\sim 0.4 \times 0.3 \mathrm{~mm}(\mathrm{c})$.

was coupled with the spatial distribution of Mactra isabelleana. This is in coincidence with the salinity range of 12-30 and the presence of muddy bottoms at which $M$. isabelleana is usually found at high densities (Giberto et al. 2004). It has been proposed that the high abundances of this deposit-feeder bivalve are related to the concentration of organic matter by frontal dynamics, and/or to the retentive properties of the front that could maintain bivalve larvae in this area (Mianzan et al. 2001, Giberto et al. 2004). At the adjacent subtidal marine zones, $R$. venosa was found near oyster (Ostrea puelchana) banks. The coexistence of $R$. venosa with these bivalves led to conjecture that it is preying over $M$. isabelleana and O. puelchana. Preliminary results on the trophic food webs in the estuary, using stable $\delta^{15} \mathrm{~N}$ and $\delta^{13} \mathrm{C}$ isotope signatures (Botto et al. In prep.), supported this hypothesis: $R$. venosa $(n=4)$ showed $\delta^{15} \mathrm{~N}$ isotopic values in an upper trophic level, over both bivalves signals. Other potential preys could be the bivalves Erodona mactroides, Corbula patagonica and Nucula puelcha, which usually inhabit the mixohaline environment (Giberto \& Bremec 2003, 望 prep., Giberto et al. 2004).

Regarding possible predators, it has been suggested that Callinectes sapidus could be a control for $R$. venosa in the Chesapeake Bay (Harding 2003), but Cesar et al. (2003) has shown that this crab (which is another exotic species in this estuary) has a diet mainly based on Limnoperna fortunei. This is an introduced bivalve typical of low salinity to freshwaters of the Río de la Plata. Other possible natural controls are demersal fishes that prey on the infauna. The whitemouth croaker, Micropogonias furnieri, is the dominant species in terms of biomass and sustains the coastal and artisanal fisheries in Argentina and Uruguay (Carozza et al. 2004). $M$. furnieri usually preys on benthic infauna including soft-bodied polychaetes and hard-bodied crustaceans, gastropods and bivalves like M. isabelleana (Puig 1986, Giberto 2001, Giberto unpublished data), using their pharyngeal teeth to crush the hard structures of these invertebrates. Therefore, M. furnieri is potentially capable of preying on $R$. venosa juveniles or at least on the egg-masses, the later confirmed recently in diets studies of this croaker (Giberto, unpublished data).

Considering the prolonged larval phase of $R$. venosa (up to 80 days), the lack of potential competitors in the estuary such as stable populations of large gastropods (Giberto et al. 2004, Carranza et al. in press, Giberto \& Bremec In prep.), and the impact of the Río de la Plata discharge along the Uruguayan and Argentine coasts, the species capable of maintaining a source population in the estuary. The vicinity of several other commercial harbors, in combination with favorable oceanographic conditions and food availability leads to the conclusion that viable populations of $R$. venosa are potentially expected in surroundings areas in a short term. The presence of $R$. venosa in muddy sediments together with the finding of egg-capsules over the specimens, and the low salinity values at which it is found in the Río de la Plata estuary, confirmed the high plasticity of $R$. venosa and the potential capability of successfully invading novel environments.

\section{ACKNOWLEDGMENTS}

The authors thank Juliana Harding, who provided thoughtful and helpful feedback on early versions of the manuscript, Fabrizio Scarabino for his valuable assistance with the data from Uruguay and Esteban Gaitan for fruitful discussions regarding stable isotopes data. Many colleagues also collaborated in the sampling on board the research cruises. Support for this work was provided by Foncyt 7-13659, Antorchas Foundation n ${ }^{\circ}$ 13900-13, Foncyt 0115080, and CONICET PIP 5009. INIDEP Contribution $n_{k}^{\circ}$

\section{LITERATURE CITED}

Acha, E. M., H. W. Mianzan, O. Iribarne, D. A. Gagliardini, C. A. Lasta \& P. Daleo. 2003. The role of the Río de la Plata bottom in accumulating debris. Mar. Pollut. Bull. 46:197-202.

Acha, E. M., H. W. Mianzan, R. Guerrero, J. Carreto, D. A. Giberto, N. Montoya \& M. O. Carignan. An Overview of Ecological Processes in the Rio de la Plata Estuary. Cont. Shelf Res. (Submitted).

Bisbal, G. A. 1995. The Southeast South American shelf large marine ecosystem. Mar. Policy 19:21-38. of resources and trophic pathways in a large Southwestern Atlantic estuary: an evaluation using stable isotopes. (in preparation).

Carozza, C., C. Lasta, C. Ruarte, C. Cotrina, H. Mianzan \& E. M. Acha. 2004. Corvina rubia (Micropogonias furnieri). In R. P. Sanchez \& S. I. Bezzi, editors. El Mar Argentino y sus recursos pesqueros. Tomo 4. Los peces marinos de interés pesquero. Caracterización biológica y evaluación del estado de explotación. Publ. Espec. Inst. Nac. Invest. Desarr. Pesq., Mar del Plata.

Carranza, A., F. Scarabino \& L. Ortega. Distribution of large benthic 
gastropods in the Uruguayan continental shelf and the Río de la Plata estuary. J. Coast. Res. (in press).

Chung, E. Y., S. Y. Kim \& Y. G. Kim. 1993. Reproductive ecology of the purple shell Rapana venosa (Gastropoda: Muricidae), with special reference to the reproductive cycle, depositions of egg capsules and hatchings of larvae. Korean J. Malacol. 9:1-15.

Drapkin, E. 1963. Effect of Rapana bezoar Linné (Mollusca, Muricidae) on the Black Sea fauna. Doklady Akademii Nauk SRR 151:700-703.

Framiñan, M. B. \& O. B. Brown. 1996. Study of the Río de la Plata turbidity front, Part I: spatial and temporal distribution. Cont. Shelf Res. 16:1259-1282.

Giberto, D. A. 2001. Feeding grounds of the whitemouth croaker Micropogonias furnieri in the Río de la Plata estuary. MSc. Thesis, Faculty of Sciences, National University of Mar del Plata, Argentina. 83 pp (in Spanish).

Giberto, D. A. \& C. S. Bremec. 2003. Benthic diversity of the Rio de la Plata estuary and adjacent marine waters. Technical report. United Nations Development Programme-Global Environmental Facilities. PNUD Project/Gef RLA/99/G31. 48 pp.

Giberto, D. A., C. S. Bremec, E. M. Acha \& H. W. Mianzan. 2004. Large-scale spatial patterns of benthic assemblages in the SW Atlantic: the Río de la Plata estuary and adjacent shelf waters. Estuar. Coast. Shelf Sci. 61:1-13.

Guerrero, R. A., E. M. Acha, M. B. Framiñan \& C. A. Lasta. 1997. Physical oceanography of the Río de la Plata estuary, Argentina. Cont. Shelf Res. 17:727-742.

Harding, J. M. 2003. Predation by blue crabs, Callinectes sapidus, on rapa whelks, Rapana venosa: possible natural controls for an invasive species? J. Exp. Mar. Biol. Ecol. 297:161-177.

Harding, J. M. \& R. Mann. 1999. Observations on the biology of the veined rapa whelk, Rapana venosa (Valenciennes, 1846) in the Chesapeake Bay. J. Shellfish Res. 18:9-17.

Harding, J. M. \& R. Mann. 2005. Veneid rapa whelk (Rapana venosa) range extensions in the Virginia waters of Chesapeake bay, USA. $J$. Shellfish Res. 24:381-385.

ICES. 2004. Alien species alert: Rapana venosa (veined whelk). In: R. Mann, A. Occhipinti, \& J. M. Harding, (editors). ICES Cooperative Research Report $\mathrm{N}^{\circ} 264.14$ pp.

Mann, R. \& J. M. Harding. 2000. Invasion of the North American Atlantic coast by a large predatory Asian mollusk. Biol. Invasions 2:7-22.
Mann, R. \& J. M. Harding. 2003. Salinity tolerance of larval Rapana venosa: implications for dispersal and establishment of an invading predatory gastropod on the North American Atlantic coast. Biol. Bull. 204:96-103.

Mianzan, H., C. Lasta, E. Acha, R. Guerrero, G. Macchi \& C. Bremec. 2001. The Río de la Plata estuary, ArgentinaeUruguay. In: U. Seeliger, L. D. de Lacerda \& B. Kjerve, editors. Coastal Marine Ecosystems of Latin America. Berlin: Springer-Verlag. pp. 185-204.

Orensanz, J. M., E. Schwindt, G. Pastorino, A. Bortolus, G. Casas, G. Darrigan, R. Elias, J. J. Lopez Gappa, S. Obenat, M. Pascual, P. E. Penchaszadeh, M. L. Piriz, F. Scarabino, E. D. Spivak \& E. A. Vallarino. 2002. No longer the pristine confines of the world ocean: a survey of exotic marine species in the southwestern Atlantic. Biol. Invasions 4:115-143.

Pastorino, G., P. E. Penchaszadeh, L. Schejter \& C. Bremec. 2000. Rapana venosa (Valenciennes, 1846) (Mollusca: Muricidae): a new gastropod in south Atlantic waters. J. Shellfish Res. 19:897-899.

Piola, A. R., E. J. D. Campos, O. O. Moller, M. Charo \& C. Martinez. 2000. Subtropical shelf front off eastern South America. J. Geophys. Res. 105:6566-6578.

Puig, P. 1986. Analysis of the stomach contents of the white croaker (Micropogon opercularis) (Sciaenidae, Perciformes). Summer 1984. Publ. Com. Tec. Mix. Frente Marit. 1:333-340. (in Spanish)

Rodrigues Capitulo, A., A. Cortelezzi, A. C. Paggi \& M. Tangorra. 2002. Phytoplankton and Benthos of the environmental survey of the Río de la Plata. $N^{\circ}$ 2. Benthos. Technical report United Nations Development Programme-Global Environmental Facilities. PNUD Project/Gef RLA/ 99/G31. 48 pp. (in Spanish).

Savini, D., M. Castellazzi, M. Favruzzo \& A. Occhipinti Ambrogi. 2004. The alien mollusc Rapana venosa (Valenciennes, 1846; Gastropoda, Muricidae) in the northern Adriatic Sea: population structure and shell morphology. Chem. Ecol. 20:S411-S424.

Scarabino, F., R. Menafra \& P. Etchegaray. 1999. Presence of Rapana venosa (Valenciennes, 1846) (Gastropoda: Muricidae) in the Río de la Plata. Bull. Urug. Zool. Soc. 11:40. (in Spanish)

Sokal, R. R. \& F. J. Rohlf. 1999. Introducción a la Bioestadística. Editorial Reverté, S. A, Barcelona. 362 pp.

Urien, C. M. 1972. Río de la Plata Estuary Environments. Geol. Soc. Am. INC. Mem. 133:213-233.

Zolotarev, V. 1996. The Black Sea ecosystem changes related to the introduction of new mollusc species. P.S.Z.N.I. Mar. Ecol. 17:227-236.
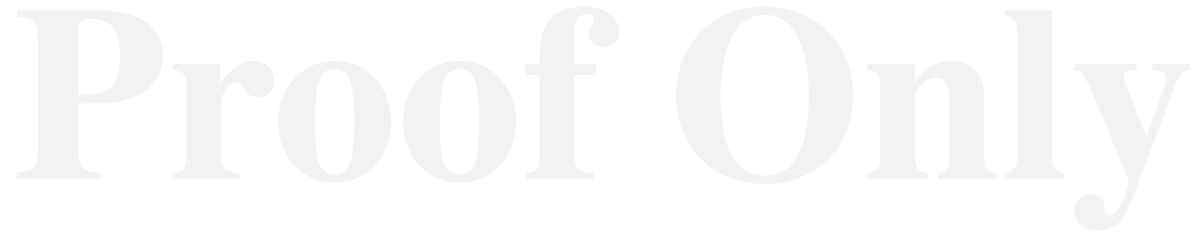